\title{
Intramolecular Charge Transfer in (Dialkylamino)nitrobiphenyls ${ }^{[1]}$
}

By Ewald Daltrozzo, Franz Effenberger, and Peter Fischer ${ }^{{ }^{*}+}$

The deep color of the new biaryls reported in the previous Communication $^{[2]}$ must be ascribed to a charge transfer (CT) transition. Since within the region $7.5 \cdot 10^{-4}$ to $7.5 \cdot 10^{-6} \mathrm{~mole} / \mathrm{liter}$ the absorption is independent of concentration, intermolecular origin of this CT interaction can be ruled out. For interpretation of intramolecular charge-transfer processes, knowledge of the molecular geometry is a prerequisite: information about the structure of the biphenyls (1) to (3) may be gained from the ${ }^{1} \mathrm{H}$ NMR spectra.

In ( $l a)$ and $(2 a)$ to $(2 f)$, the signals of the ortho-pyrrolidino groups are shifted to higher field by about $0.30 \mathrm{ppm}$ ( $\beta$-methylene protons) and $0.60 \mathrm{ppm}\left(\mathrm{N}-\mathrm{CH}_{2}\right.$ ) respectively, relative to those of the para-amino substituents (Table 1). Improved shielding due to steric hindrance of resonance by the nitrophenyl substituents ${ }^{[2]}$ does not suffice to account for these large shifts, especially of the $\beta-\mathrm{CH}_{2}$ hydrogen nuclei ${ }^{[3]}$; it must rather be assumed that the ortho-dialkyl-

[*] Prof. Dr. F. Effenberger and Dr. P. Fischer Institut für Organische Chemie der Universität

7 Stuttgart, Azenbergstr. 14-18 (Germany)

Dr. E. Daltrozzo

Institut für Physikalische Chemie und Elektrochemie

der Technischen Universität

8 Múnchen 2, Arcisstr. 21 (Germany) 
amino groups protrude deep into the diamagnetic anisotropy field of the nitrobenzene. The characteristic structure of the methylene multiplets, though, is not split further; within the NMR-time scale, the $\mathrm{NR}_{2}$ groups must therefore be placed symmetrically with respect to the plane of the nitroarene [cf. (4)].
Admixture of contact charge transfer in chlorinated hydrocarbons gives a bathochromic shift. As has been observed for tetracyanoethylene ${ }^{[6]}, \mathrm{CH}_{2} \mathrm{Cl}_{2}$ is a far more effective donor than $\mathrm{CCl}_{4}$; for interaction of the amino system with halomethanes as acceptors ${ }^{[7]}$, the opposite effect is to be expected

Table 1. ${ }^{1} \mathrm{H}-\mathrm{NMR}$ data and longest-wave UV absorptions of biphenyls (1) to (3).

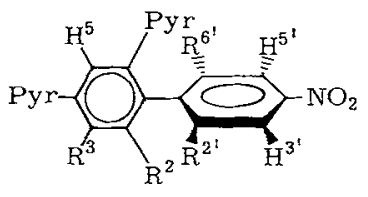

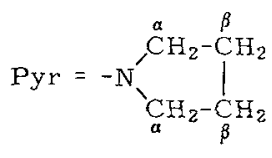

\begin{tabular}{|c|c|c|c|c|c|c|c|c|c|c|}
\hline & $\mathrm{R}^{2}$ & $R^{3}$ & $\mathrm{R}^{2}$ & $\mathrm{R}^{6}$ & $\begin{array}{l}\text { NMR }(\tau \text { value } \\
\text { Pyr, } \beta-\mathrm{H}[\mathrm{a}]\end{array}$ & $\begin{array}{l}\text { s); } 0.5 \mathrm{M} \text { in DC } \\
\text { Pyr, } \alpha-\mathrm{H}[\mathrm{a}]\end{array}$ & $\begin{array}{c}\mathrm{Cl}_{3}, \text { int. TA } \\
\mathrm{H}^{3,5}\end{array}$ & & $\begin{array}{l}30 \mathrm{C}^{\circ} \\
\mathrm{H}^{3 ;} 5^{\prime}\end{array}$ & $\begin{array}{l}\lambda_{\max }(n m) \\
\left(\varepsilon_{\max }\right)[\mathrm{b}]\end{array}$ \\
\hline (1a) & Pyr & $\mathrm{CH}_{3}$ & $\mathrm{NO}_{2}$ & $\mathrm{NO}_{2}$ & $\begin{array}{l}8.28(\mathrm{o}) \\
8.05(\mathrm{p})\end{array}$ & $\begin{array}{l}7.22(\mathrm{o}) \\
6.73(\mathrm{p})\end{array}$ & 3.57 & & 1.19 & $548.5 ;(3520)$ \\
\hline (2a) & Pyr & $\mathrm{H}$ & $\mathrm{NO}_{2}$ & $\mathrm{NO}_{2}$ & $\begin{array}{l}8.30(\mathrm{o}) \\
7.99(\mathrm{p})\end{array}$ & $\begin{array}{l}7.26(0) \\
6.65(p)\end{array}$ & 4.01 & & 1.26 & $561.5 ;(5750)$ \\
\hline$(2 b)$ & Pyr & $\mathrm{H}$ & $\mathrm{CN}$ & $\mathrm{NO}_{2}$ & $\begin{array}{l}8.29(\mathrm{o}) \\
7.99(\mathrm{p})\end{array}$ & $\begin{array}{l}7.23(\mathrm{o}) \\
6.63(\mathrm{p})\end{array}$ & 3.97 & $\begin{array}{l}\mathrm{H}^{3^{3}} \\
\mathrm{H}^{5^{\prime}}\end{array}$ & $\begin{array}{l}1.36 \\
1.19\end{array}$ & $532.5 ;(5940)$ \\
\hline (2c) & Pyr & $\mathrm{H}$ & $\mathrm{COOCH}_{3}$ & $\mathrm{NO}_{2}$ & $\begin{array}{l}8.32(0) \\
7.99(p)\end{array}$ & $\begin{array}{l}7.28(0) \\
6.65(p)\end{array}$ & 4.01 & & $\begin{array}{l}1.31 \\
1.28\end{array}$ & $530.5 ;(5660)$ \\
\hline (2d) & Pyr & $\mathrm{H}$ & $\mathrm{COOH}$ & $\mathrm{NO}_{2}$ & $\begin{array}{l}8.22(\mathrm{o}) \\
7.96(\mathrm{p})\end{array}$ & $\begin{array}{l}7.14(0) \\
6.65(p)\end{array}$ & 3.97 & & $\begin{array}{l}1.41 \\
1.22\end{array}$ & $466 ;(3480)$ \\
\hline$(2 e)$ & Pyr & $\mathrm{H}$ & $\mathrm{H}$ & $\mathrm{NO}_{2}$ & $\begin{array}{l}8.31(\mathrm{o}) \\
7.99(\mathrm{p})\end{array}$ & $\begin{array}{l}7.26(\mathrm{o}) \\
6.65(\mathrm{p})\end{array}$ & 4.01 & $\begin{array}{l}\mathrm{H}^{3} \\
\mathrm{H}^{5} \\
\mathrm{H}^{2^{\prime}}\end{array}$ & $\begin{array}{l}1.32 \\
1.71 \\
2.31\end{array}$ & $510.5 ;(5790)$ \\
\hline$(2 f)$ & Pyr & H & $\mathrm{H}$ & CN & $\begin{array}{l}8.31(\mathrm{o}) \\
7.99(\mathrm{p})\end{array}$ & $\begin{array}{l}7.24(\mathrm{o}) \\
6.64(\mathrm{p})\end{array}$ & 3.99 & $\begin{array}{l}\mathrm{H}^{3^{\prime}} \\
\mathrm{H}^{5^{\prime}} \\
\mathrm{H}^{2^{\prime}}\end{array}$ & $\begin{array}{l}1.52 \\
1.70 \\
2.32\end{array}$ & $472 ;(6230)$ \\
\hline (3a) & $\mathrm{H}$ & $\mathrm{H}$ & $\mathrm{NO}_{2}$ & $\mathrm{NO}_{2}$ & $\begin{array}{l}8.23(\mathrm{o}) \\
7.98(\mathrm{p})\end{array}$ & $\begin{array}{l}7.09(\mathrm{o}) \\
6.65(\mathrm{p})\end{array}$ & $\begin{array}{ll}\mathrm{H}^{2} & 3.14 \\
\mathrm{H}^{3} & 3.61 \\
\mathrm{H}^{5} & 3.93\end{array}$ & & 1.32 & $533 ;(5960)$ \\
\hline
\end{tabular}

[a] (o) denotes pyrrolidino substituents in the 2- and 6-positions, (p) those in the p-position to the biphenyl linkage; in each case, the center of the characteristic multiplet is given as the signal position.

[b] $7.5 \times 10^{-5} \mathrm{M}$ in $\mathrm{CH}_{3} \mathrm{CN}$.

In (2d), a hydrogen bridge can be formed from the $\mathrm{COOH}$ group to the ortho-dialkylamino-nitrogen; the resulting decrease in electron density on the $\mathrm{N}$-atom shifts the $\mathrm{N}-\mathrm{CH}_{2}$ signal by $-0.14 \mathrm{ppm}$. This shows how sensitive the NMR signals are even to small changes in structure.

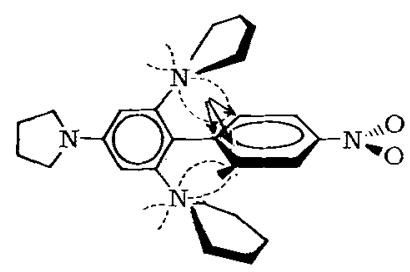

Therefore the fact that the $\mathrm{H}^{3^{3}, 5^{\prime}}$ signal position is almost identical for $(2 a)$ to $(2 f)$ (while electron affinities of the nitrophenyl units differ widely) seems to us good proof that in the ground state there is no significant interaction between the two aromatic component systems.

While several papers on intramolecular $C T$ complexes have recently been published ${ }^{[4]}$, intramolecular CT interaction in biphenyls has not been observed previously. The near constancy of the band position for (2a) over a series of solvents (Table 2) again ascertains the intramolecular origin of the longest-wave absorption of $(1)$ to (3).
Gradation of band positions in the order $(2 a) \rightarrow(1 a) \rightarrow(3 a)$ $(561.5,548.5,533 \mathrm{~nm})$, as well as for the sequence $(2 a) \rightarrow(2 f)$, shows the energy of the CT transition to be determined by both the electron density of the amino and the electron affinity of the acceptor component. There is no straightforward correlation, though, with the $E_{1 / 2}^{\text {Red }}$ values of the nitroarenes.

For an interpretation of the charge transfer several possible mechanisms must be taken into account :

(a) interaction of the n-electron pair of one ortho-nitrooxygen atom and orbitals of C-2 and C- 6 of the aromatic amine;

(b) direct interaction between the lone pair of the orthopyrrolidino nitrogen and, particularly, positions $1^{\prime}, 2^{\prime}$, and 6 of the aromatic nitro compound [see (4)];

(c) "normal" charge transfer from the electron-rich amino to the electron-deficient nitro component (overlap between $\mathrm{p}_{z}$ orbitals of one aromatic system and $\sigma$ orbitals of bonds $1-2$ and $1-6$ of the other arene).

Transfer between the amino benzene and the ortho-nitro groups as in (a) is rather unlikely since, on the basis of orbital symmetry, there is no bonding interaction between any of the molecular orbitals participating in the longwave transitions. By PPP calculations ${ }^{[8]}$, position and intensity of the lowest-energy absorption may be reprod- 
uced satisfactorily even without taking process (b) into account, and without specific adjustment of parameters ${ }^{[9,10]}$ Thus, in the first electron transition (CT band), charge is transferred primarily from the ortho nitrogen atoms and from $\mathrm{C}-1$ of the aminobenzene to $\mathrm{C}-1^{\prime}$ and the ortho-nitro groups of the second component; hyperconjugative $\sigma-\pi$ interaction as in (c) has been taken into account by introducing pseudo- $\pi$ centers.

Table 2. Lowest-energy UV-absorption bands of $(2 a)$ in various solvents.

\begin{tabular}{lrrrrrrrr}
\hline & $\mathrm{C}_{6} \mathrm{H}_{12}$ & $\mathrm{CCl}_{4}$ & Dioxane & $\begin{array}{l}\text { Dimeth- } \\
\text { oxyethane }\end{array}$ & $\mathrm{CH}_{2} \mathrm{Cl}_{2}$ & Acetone & $\mathrm{CH}_{3} \mathrm{CN}$ & $\mathrm{CH}_{3} \mathrm{OH}$ \\
\hline$E_{\mathrm{T}^{-v} \text { alue }[5]}$ & 31.2 & 32.5 & 36.0 & 38.2 & 41.1 & 42.2 & 46.0 & 55.5 \\
$\tilde{v}\left(\mathrm{~cm}^{-1}\right)$ & 17940 & 17610 & 17970 & 17950 & 17040 & 17860 & 17810 & 18050 \\
$\Delta \tilde{v}_{1 / 2}\left(\mathrm{~cm}^{-1}\right)$ & 3730 & 3930 & 4620 & 5010 & 4620 & 5090 & 5090 & 5250 \\
$\varepsilon_{\max }$ & 7240 & 7030 & 5720 & 5740 & 6300 & 5690 & 5750 & 5560 \\
\hline
\end{tabular}

An estimate as to the relative contributions of mechanisms (b) and (c) to the charge transfer observed will be possible as soon as dialkylamino biphenyls become available with different gradation between $\mathrm{N}$-basicity and $\pi$-electron density at the free aromatic ring positions.

$$
\text { Received: May 17, } 1971 \text { [Z } 443 \text { b IE] }
$$

German version: Angew. Chem. 83, 621 (1971)

[1] We thank the Deutsche Forschungsgemeinschaft and the Fonds der Chemischen Industrie for support of this work.

[2] F. Effenberger, K. Nagel, and W. Agster, Angew. Chem. 83, 619 (1971); Angew. Chem. internat. Edit. 10, 566 (1971).

[3] The appreciably more bulky isopropyl group causes a shift to higher field of only $0.25(\alpha-\mathrm{H})$ or $0.07 \mathrm{ppm}(\beta-\mathrm{H})$; because of the strongly anisotropic $\mathrm{NO}_{2}$ groups an additional paramagnetic shift is also to be expected.

[4] K. Mutai, Tetrahedron Lett. 1971,$1125 ; H$. A. H. Craenen, J.W. Verhoeven, and Th. J. de Boer, ibid. 1970,1167; for a review of previous literature see $R$. Foster, Organic Charge Transfer Complexes, Academic Press, London 1969, p. 78.

[5] Ch. Reichardt and K. Dimroth, Fortschr. Chem. Forsch. 11,1 (1969).

[6] R. X. Ewall and A.J. Sonnessa, J. Amer. Chem. Soc. 92, 2845 (1970).

[7] K. M. C. Davis and M. F. Farmer, J. Chem. Soc. B $1968,859$.

[8] R. Pariser and R. G. Parr, J. Chem. Phys. 21, 466, 767 (1953); J. A. Pople, Trans. Faraday Soc. 49, 1375 (1953).

[9] Parametrization: F. Dörr, G. Hohlneicher, and S. Schneider, Ber Bunsenges. Phys. Chem. 70, 806 (1966).

[10] We thank Drs. G. Hohlneicher and S. Schneider for supplying the computer program. The calculations were carried out on the TR4 installation at the Leibniz-Rechenzentrum of the Bayerische Akademie der Wissenschaften. 